\title{
Membangun Negeri Dengan Wakaf Produktif
}

\author{
Dini Selasi \\ Institut Agama Islam Bunga Bangsa Cirebon \\ diniselasi1980@gmail.com
}

\begin{abstract}
Waqf has a function of worship activities, namely by holding our assets to be used in the way of Allah SWT which gives rewards throughout the ages will also have a social function which after the principal of the property is withheld, developed then after being developed will provide results that can be used by the people. This research aims to provide education about the role of waqf in development as well as how the role of waqf for the welfare of the people. This research uses qualitative research methods, data collection techniques using secondary data and using literature study. The results of this study show that waqf has an important role in providing the welfare of the people and waqf also has an important role in developing the country, this is evidenced by the role of waqf in the fields of education, health, economy and finance, technology and agriculture, where these fields are the pillars of development national.
\end{abstract}

Keywords: development, waqf, productive waqf, welfare

\begin{abstract}
Abstrak
Wakaf memiliki fungsi kegiatan ibadah yaitu dengan menahan harta kita untuk digunakan di jalan Allah SWT yang memberikan pahala sepanjang zaman juga akan memiliki fungsi sosial yang setelah pokok harta ditahan, dikembangkan kemudian setelah dikembangkan akan memberikan hasil yang dapat digunakan oleh masyarakat. Penelitian ini bertujuan untuk memberikan edukasi tentang peran wakaf dalam pembangunan serta bagaimana peran wakaf bagi kesejahteraan umat. Penelitian ini menggunakan metode penelitian kualitatif, teknik pengumpulan data menggunakan data sekunder dan menggunakan studi kepustakaan. Hasil penelitian ini menunjukkan bahwa wakaf memiliki peran penting dalam memberikan kesejahteraan umat dan wakaf juga memiliki peran penting dalam membangun negara, hal ini dibuktikan dengan peran wakaf dalam bidang pendidikan, kesehatan, ekonomi dan keuangan, teknologi dan pertanian, dimana bidang-bidang tersebut menjadi pilar pembangunan nasional.
\end{abstract}

Kata kunci: pembangunan, wakaf, wakaf produktif, kesejahteraan

\section{PENDAHULUAN}

Salah satu filantropi Islam adalah wakaf yang sudah sangat akrab bagi umat muslim. Wakaf merupakan salah satu filantropi Islam yang dapat memberikan manfaat bagi masyarakat secara luas, wakaf ini sudah ada sejak zaman Rasullulah dan pada masa para sahabatnya seperti masa Umar bin Khatab, Abu Thalhah yang disesuaikan pada masa itu kemudian wakaf berkembang sampai saat ini (Nissa, 2017). Dalam Islam jika kita berlebihan dalam pendapatan dalam hal ini adalah harta maka makin besarlah 
tanggung jawab kita untuk bisa mempertanggung jawabkan harta tersebut kepada Allah dengan jalan menyedekahkan di jalan Allah melalui zakat, infaq, shadaqah serta wakaf.

Wakaf menjadi satu bahasan dalam penelitian saat ini, seperti yang diajarkan dalam Islam bahwa harta kita pada hakekatnya tidak sepenuhnya hak kita tetapi dalam harta kita ada hak orang lain juga, bisa disalurkan melalui wakaf sebagai bentuk pelepasan harta kita untuk dibelanjakan di jalan Allah sehingga bisa di manfaatkan oleh masyarakat serta untuk meningkatkan kesejahteraan masyarakat sementara itu wakaf di Indonesia dikenal serta dipraktekkan sejak umat Islam datang ke Indonesia untuk pertama kalinya (Itang \& Syakhabyatin, 2017). Berwakaf memberikan dampak yang luar biasa bagi kesejahteraan masyarkat, pada masyarakat secara umum wakaf sebagai pemberian dalam bentuk barang tidak bergerak seperti tanah, gedung dimana pemanfaatannya hanya sebatas untuk pembangunan rumah ibadah dan sarana pendidikan, namun sebenarnya wakaf untuk barang bergerak (wakaf tunai atau wakaf uang) sudah di peraktekkan sejak masa dinasti bani Umayah dan bani Abbasiyah yang pemanfaatannya untuk kesejahteraan masyarkat (Said \& Amiruddin, 2019).

Menurut Fahruroji sebagai wakil sekretaris Badan Wakaf Indonesia (BWI) menjelaskan bahwa tujuan berwakaf adalah untuk ibadah, sosial dan ekonomi, tujuan ibadah yaitu untuk mencari ridha Allah SWT sementara untuk tujuan sosial yaitu untuk menyediakan fasilitas umum, kegiatan dakwah, ibadah, pendidikan serta kesehatan selain tujuan tersebut wakaf dalam kegiatan ekonomi yaitu untuk memperluas lapangan kerja, permodalan serta membantu meningkatkan ekonomi umat dan ekonomi negara dengan berwakaf dapat membantu beban anggaran negara (Fahrurroji, 2020). Salah satu lembaga independen yang menangani seluruh kegiatan wakaf di Indonesia adalah Badan Wakaf Indonesia yang dibentuk berdasarkan UU nomor 41 tahun 2004 (Presiden Republik Indonesia, 2006) yang memiliki peran penting dalam perkembangan wakaf di Indonesia seperti pembinaan nadzir yang profesional, melibatkan mitra bisnis strategis dalam bidang jasa keuangan yang berbasis syariah kesemuanya itu untuk mensejahterakan masyarakat melalui wakaf (Aziz, 2017).

Perkembangan wakaf di Indonesia melibatkan banyak pihak diantaranya adalah Badan Wakaf Indonesia (BWI), Dompet Dhuafa, Badan Waqaf Al Qur'an, Lembaga Wakaf Ma'had Ibnussabil Indonesia, Lembaga Wakaf dan Pertahanan NU (Laz DD, 2019) lembaga-lembaga tersebut merupakan lembaga yang menyalurkan, mengembangkan dan memberikan manfaat atas wakaf bagi kesejahteraan umat. Dalam penerapan wakaf di Indonesia peruntukkannya sebatas pada tempat ibadah, pemakamaman serta pendidikan, namun seiring perkembangan dalam masyarakat saat ini ada wakaf tunai dengan menggunakan uang tunai, menurut penelitian yang 
dilakukan oleh Yuliafitri (Yuliafitri \& Rivaldi, 2017) bahwa penggunaan prinsi good governance dan penerapan prinsip tata kelola serta promosi secara simultan berpengaruh positif terhadap penerimaan dana wakaf tunai.

Dengan latar belakang tersebut, dalam penelitian ini bertujuan untuk mengetahui bagaimana dampak perkembangan wakaf (konvensional, tunai, produktif) terhadap pembangunan di Indonesia dimana didalamya mengandung unsur peruntukkan, sumber wakaf, bukti nyata yang bisa dimanfaatkan oleh umat secara umum serta dapat merubah kesejahteraan masyarakat.

\section{KAJIAN LITERATUR}

Regulasi pengelolaan wakaf di Indonesia dimulai sejak zaman kolonial Belanda, wakaf sebagai institusi keuangan Islam dengan berdirinya pegadilan agama berdasarkan staasblad nomor 152 tahun 1882 yang diajukan ke Mahkamah Syar'iyah atau pengadilan agama dengan penetapan yang berbeda-beda seriap daerahnya, kemudian setelah kemerdekaan muncul PP nomor 28 tahun 1977 tentang Perwakafan Tanah Milik kemudian berkembang dengan dikeluarkannya UU no.41 tahun 2004 tentang wakaf sehingga pengeloaan wakaf lebih baik, kreatif dan inovatif (Dahlan, 2016).

\section{Dasar Hukum}

Dalam Al-Qur'an dijelaskan "Hai orang-orang yang beriman, nafkahkanlah (di jalan Allah) sebagian dari hasil usahamu yang baik-baik dan sebagian dari apa yang Kami keluarkan dari bumi untukmu. Dan janganlah kalian memilih yang buruk-buruk lalu kalianmenafkahkandaripadanya, padahal kaliansendiri tidak mau mengambilnya melainkan dengan memincingkan mata terhadapnya. Dan ketahuilah, bahwa Allah Maha Kaya lagi Maha Terpuji."(QS. al-Baqarah: 267).

Ayat lainnya menerangkan bahwa "Kalian sekali-kali tidak sampai kepada kebajikan (yang sempurna), sebelum kalian menafkahkan sebagian harta yang kalian cintai, dan apa saja yang kalian nafkahkan maka sesungguhnya Allah mengetahuinya." (QS. Ali Imran: 92).

Terkadang wakaf masih disamakan pengertiannya dengan zakat, infaq dan shadaqah namun ternyata berbeda, berikut adalah pengertian wakaf antara lain :

1. Wakaf adalah perbuatan hukum Wakif untuk memisahkan dan/atau menyerahkan sebagian harta benda miliknya untuk dimanfaatkan selamanya atau untuk jangka waktu tertentu sesuai dengan kepentingannya guna keperluan ibadah dan/atau kesejahteraan umum menurut syariah (Presiden Republik Indonesia, 2006) 
2. Berhenti, tetap dalam keadaan semula ; pemindahan hak pribadi menjadi milik suatu badanyag akan memberi manfaat bagi masyarakat ; perbuatan hukum wakif untuk memisahkan dan/atau menyerahkan sebagian harta benda miliknya untuk dimanfaatkan selaanya atau untuk jangka panjang waktu sesuai dengan kepentingannya guna keperluan ibadah dan/atau kesejahteraan umum menurut syariah (Sholihin, 2010).

3. Menahan, menahan harta untuk diwakafkan, tidak dipindahmilikkan (BWI, 2020a).

4. Wakaf diambil dari kata wakaf (Arab: وقوقاف aqf; plural Arab: وقف) awqāf; bahasa Turki: vakıf, bahasa Urdu: وقف) yang artinya "menahan" atau "berhenti". Sebagai satu istilah dalam syariah Islam, wakaf diartikan sebagai penahanan hak milik atas materi benda (al-'ain) untuk tujuan menyedekahkan manfaat atau faedahnya/al-manfa'ah (al-Jurjani: 328) (Sari, 2018).

\section{Rukun wakaf dan syarat wakaf}

Di dalam Islam sudah menjadi ketentuan yang harus dipenuhi jika akan melakukan suatu transaksi yaitu harus terpenuhinya rukun dan syarat dalam akad tersebut, dalam hal ini untuk melakukan transaksi atau akad wakaf baik wakaf uang atau terhadap wakaf produktif. Berikut adalah rukun wakaf dan syarat wakaf (Kamaluddin, 2020)

Rukun wakaf

1. Wakif; orang yang mewakafkan hartanya

2. Muwaqif; barang yang diwakafkan

3. Mawaqif'alaihi; penerima wakaf

4. Shighah; lafal wakaf

Syarat wakaf

1. Syarat bagi pewakif; orang merdeka, berakal, baligh, dewasa.

2. Harta yang di wakafkan; bisa diukur nilainya, diketahui ukurannya, milik pewakaf bukan milik umum.

3. Shighah wakaf; berlaku untuk selamanya, langsung dilaksanakan, keharusan melaksanakan, tidak dikaitkan dengan syarat yang batal, tidak membatasi ikrar wakaf.

Jenis Wakaf

Wakaf sebagai filantropi ddalam Islam memiliki berbagai jenis wakaf yang disesuaikan dengan kebutuhan masyarakat, berikut adalah jenis wakaf menurut beberapa kriteria menurut Lahuri (Lahuri, 2020) :

1. Berdasarkan batas waktunya.

2. Berdasarkan penggunaannya.

3. Berdasarkan cakupannya

4. Berdasarkan manfaatnya.

5. Berdasarkan bentuk manajemennya. 
6. Berdasarkan jenis barangnya.

7. Berdasarkan keadaaan wakifnya.

\section{METODOLOGI PENELITIAN}

Penelitian ini menggunakan penelitian kualitatif dimana peneliti terjun langsung menjadi in strumen utama dalam penelitian pada saat mengumpulkan data (Zuchdi Darmiyati Afifah, 2019). Penelitian ini menggunakan teknik pengumpulan datanya dengan menggunakan pengamatan partisipasif dalam kegiatan-kegiatan webinar yang terkait dengan penelitian ini, data yang digunakan data yang dilakukan menggunakan data sekunder dengan teknik pengumpulan data dilakukan dengan studi kepustakaan yang kemudian dianalisis secara kualitatif yang diperoleh dari berbagai dokumen seperti data statistik, jurnal ilmiah, bukubuku juga kegiatan seminar, thesis sehingga penulis bisa terbantu untuk membuat kesimpulan.

\section{HASIL DAN PEMBAHASAN \\ Hasil Analisis Data}

Penelitian ini menggunakan analisis dengan menggunakan data-data sekunder yang berasal dari berbagai jurnal-jurnal ilmiah, kegiatan webinar online, web site serta data-data statistik yang menunjang penelitian ini sehingga menghasilkan hasil yang menunjukkan bahwa wakaf mempunyai peranan penting dalam kegiatan ekonomi serta pembangunan nasional. Wakaf memberikan manfaat bagi mauquf 'alaihi sehingga mereka lebih sejahtera dalam kehidupannya lebih jauh lagi wakaf memberikan kontribusi bagi pembangunan negeri seperti dalam bidang pendidikan, kesehatan, pertanian, ekonomi dan keuangan, teknologi, hal ini menunjukkan bahwa hampir disemua bidang wakaf bisa berkontribusi dalam pembangunan negeri.

\section{Pembahasan}

\section{Perkembangan wakaf di Indonesia}

Lembaga wakaf mempunyai paradigma (Naim, 2019) yaitu bagi kesejahteraan masyarakat (market orientation ) yang mempunyai oreintasi pada donatur dan pada dhuafa sebagai penerima wakaf, harus mempunyai data, memastikan programnya sesuai dengan keinginan wakif, memastikan program pendayagunaan dana bisa menjadi problem solver, perencanaan dan pelaksanaan program tetap dalam syariah serta amanah dan profesional, integralitas dan sinergisitas program penting agar program tersebut efisien, efektif dan produktif. Wakaf mempunyai nilai ekonomi sebagai sumber dana potensial untuk dikembangkan, dimanfaatkan, dikelola untuk menghasilkan hasil yang optimal oleh karena 
itu harus dibentuk kemitraan yang dibentuk oleh masyarakat dan yang dibentuk oleh pemerintah (Hadi, 2018).

Peran wakaf sebagai salah satu instrumen ekonomi Islam yang dapat memberikan manfaat bagi masyarakat, beberapa negara telah menunjukkan keberhasilan dalam mengelola wakaf dan memberikan manfaat bagi masyarakatnya seperti Mesir, Malaysia, Turki bahkan Amerika begitupun dengan Indonesia memiliki potensi besar akan wakaf yang bisa menjadi solusi dari masalah kemiskinan agar lebih sejahtera (Fuadi, 2018). Berdasarkan jenis wakaf menurut penggunaannya ada wakaf langsung (mubaaasyir) dan wakaf produktif (istimaarariy) yang banyak berlaku di Indonesia (Lahuri, 2020).

Pemanfaatan wakaf langsung bisa digunakan untuk pendanaan, kegiatan sosial dan pendidikan serta kesehatan sebagai pilar utama untuk kesejahteraan umat dengan konsep revitaslisasi yang merupakan suatu cara yang sangat penting dan diperlukan untuk memberikan dampak positif yang dirasakan langsung mampu mampu membentuk pengeloaan wakaf profesional untuk menghasilkan kesejahteraan umat secara luas (Lestari, 2018). Berikut adalah beberapa jenis wakaf langsung artinya wakaf tersebut bisa dirasakan langsung manfaatnya oleh umat seperti wakaf tanah (Siwak Kemenag, 2020a)

Tabel 1.

Jumlah Tanah Wakaf Seluruh Indonesia

\begin{tabular}{|r|l|r|r|r|r|r|r|}
\hline \multirow{2}{*}{ No } & \multirow{2}{*}{ Nama Wilayah } & \multirow{2}{*}{ Jumlah } & \multirow{2}{*}{ Luas [Ha] } & \multicolumn{2}{c|}{ Sudah Sertifikat } & \multicolumn{2}{|c|}{ Belum Sertifikat } \\
\cline { 6 - 8 } & & & Jumlah & $\begin{array}{c}\text { Luas } \\
{[\text { Ha] }}\end{array}$ & Jumlah & Luas [Ha] \\
\hline 1 & Aceh & 15.491 & $8.491,31$ & 7.464 & $1.016,79$ & 8.027 & $7.474,52$ \\
\hline 2 & Sumatera Utara & 10.858 & $7.718,61$ & 6.261 & 793,56 & 4.597 & $6.925,05$ \\
\hline 3 & Sumatera Barat & 5.247 & 598,73 & 3.611 & 373,49 & 1.636 & 225,24 \\
\hline 4 & Riau & 8.142 & $2.097,86$ & 2.816 & 457,64 & 5.326 & $1.640,23$ \\
\hline 5 & Jambi & 6.46 & $1.030,13$ & 3.558 & 451,54 & 2.902 & 578,59 \\
\hline 6 & Sumatera Selatan & 3.97 & 945,06 & 1.964 & 147,03 & 2.006 & 798,03 \\
\hline 7 & Bengkulu & 2.294 & 408,69 & 1.643 & 235,17 & 651 & 173,52 \\
\hline 8 & Lampung & 12.872 & $5.646,86$ & 7.369 & $2.826,19$ & 5.503 & $2.820,67$ \\
\hline 9 & Kep. Bangka Belitung & 1.089 & 203,47 & 749 & 150,42 & 340 & 53,06 \\
\hline 10 & Kepulauan Riau & 1.49 & 311,10 & 476 & 64,84 & 1.014 & 246,26 \\
\hline 11 & D K I Jakarta & 6.595 & 266,20 & 4.074 & 157,45 & 2.521 & 108,75 \\
\hline 12 & Jawa Barat & 73.251 & $5.227,29$ & 39.153 & $2.229,44$ & 34.098 & $2.997,84$ \\
\hline 13 & Jawa Tengah & 100.918 & $5.158,86$ & 73.423 & $3.674,26$ & 27.495 & $1.484,60$ \\
\hline 14 & D I Yogyakarta & 10.205 & 363,36 & 9.202 & 324,68 & 1.003 & 38,68 \\
\hline 15 & Jawa Timur & 67.175 & $4.405,77$ & 35.32 & $2.265,01$ & 31.855 & $2.140,76$ \\
\hline 16 & Banten & 15.424 & $1.074,61$ & 8.582 & 553,12 & 6.842 & 521,49 \\
\hline
\end{tabular}




\begin{tabular}{|r|l|r|r|r|r|r|r|}
17 & 1.455 & 212,53 & 1.304 & 186,31 & 151 & 26,22 \\
\hline 18 & Nusa Tenggara Barat & 9.22 & $1.409,96$ & 5.827 & 884,76 & 3.393 & 525,20 \\
\hline 19 & Nusa Tenggara Timur & 1.307 & 335,26 & 985 & 209,90 & 322 & 125,36 \\
\hline 20 & Kalimantan Barat & 2.746 & 538,49 & 1.555 & 246,36 & 1.191 & 292,13 \\
\hline 21 & Kalimantan Tengah & 3.046 & 613,39 & 1.84 & 339,77 & 1.206 & 273,63 \\
\hline 22 & Kalimantan Selatan & 8.206 & 985,59 & 7.228 & 832,76 & 978 & 152,83 \\
\hline 23 & Kalimantan Timur & 2.583 & 662,24 & 1.255 & 198,23 & 1.328 & 464,01 \\
\hline 24 & Kalimantan Utara & 436 & 138,11 & 165 & 99,73 & 271 & 38,38 \\
\hline 25 & Sulawesi Utara & 775 & 102,78 & 344 & 34,40 & 431 & 68,37 \\
\hline 26 & Sulawesi Tengah & 2.147 & 895,17 & 1.377 & 139,37 & 770 & 755,81 \\
\hline 27 & Sulawesi Selatan & 7.109 & 905,78 & 4.432 & 361,20 & 2.677 & 544,58 \\
\hline 28 & Sulawesi Tenggara & 1.108 & 110,58 & 827 & 71,37 & 281 & 39,21 \\
\hline 29 & Gorontalo & 1.881 & 385,50 & 949 & 272,60 & 932 & 112,90 \\
\hline 30 & Sulawesi Barat & 2.906 & 420,46 & 975 & 117,00 & 1.931 & 303,45 \\
\hline 31 & Maluku & 469 & 121,36 & 213 & 38,96 & 256 & 82,39 \\
\hline 32 & Maluku Utara & 313 & 46,72 & 225 & 25,37 & 88 & 21,35 \\
\hline 33 & Papua & 287 & 59,97 & 141 & 19,28 & 146 & 40,69 \\
\hline 34 & Papua Barat & 50 & 20,17 & 35 & 6,19 & 15 & 13,98 \\
\hline & Jumlah & 387.525 & $51.911,95$ & 235.342 & $19.804,18$ & 152.183 & $32.107,77$ \\
\hline
\end{tabular}

Sumber : kemenag.go.id

Berdasarkan data tersebut pemanfaatan tanah wakaf dengan jumlah luas tanah wakaf sebanyak 52.911 Ha dengan jumlah tanah yang sudah bersertifikat sebanyak 152.183 atau kira-kita sebesar $60,73 \%$ yang tersebar pada 387.533 lokasi di seluruh Indonesia, berikut adalah peruntukkan penggunaan tanah wakaf di Indonesia (Siwak Kemenag, 2020b):

Tabel 2.

Penggunaan Tanah Wakaf

\begin{tabular}{|l|l|c|}
\hline Penggunaan Tanah Wakaf & $\begin{array}{l}\text { Banyaknya } \\
\text { Lokasi }\end{array}$ & Prosentase \\
\hline Masjid & 170.923 & $44,24 \%$ \\
\hline Mushola & 109.867 & $28,44 \%$ \\
\hline Sekolah & 41.281 & $10,68 \%$ \\
\hline Kegiatan Sosial & 33.411 & $8,65 \%$ \\
\hline Makam & 17.153 & $4,44 \%$ \\
\hline Pesantren & 13.716 & $3,55 \%$ \\
\hline
\end{tabular}

Sumber : kemenag.co.id

Menurut penelitian yang dilakukan Nizar (Nizar, 2017) wakaf produktif mempunyai prospek yang sangat bagus bagi pembangunan, dengan menggunakan perhitungan aset tetap dan aset bergerak (wakaf tunai) bahwa wakaf tanah terluas di dunia sebesar 440.512, 89 ha dengan 
peruntukan rumah ibadah (masjid dan mudshola) sebesar 73\%, fasilitas pendidikan, kuburan dan kegiatan sosial lainnya sebesar 13,3\% jika aset wakaf di kembangkan secara produktif ada sekitar 19,4\% dari Produk Domestik Bruto (PDB) disumsikan umat Islam berwakaf Rp.10.000per bulan maka dana yang didapatkan sekitar Rp. 2,36 triliun per tahun dan dana tersebut berpotensi dari Jawa Barat, maka dari data tersebut wakaf itu mempunyai potensi yang sangat besar untuk bisa dimanfaatkan sehingga tumbuhnya kesejahteraan bagi umat.

Dengan potensi wakaf yang sangat besar, ada beberapa kekurangan dalam pengelolaannya yaitu untuk masalah internal kurangnya kompetensi dan profesionalisme nadzir sebagai pengelola muaqif atau barang yang diwakafkan sementara permasalahan eksternalnya adalah kurangnya pemahaman tentang wakaf dan regulasinya, untuk itu peran BWI sangat penting untuk memperbaiki regulasi serta melakukan sosialisai, edukasi wakaf (Ali, Yuliani, Mulatsih, \& Abdullah, 2018).

Wakaf memiliki fungsi sebagai salah satu ibadah kepada Allah SWT dan wakaf juga berfungsi sosial dimana pemanfaatannya bisa dirasakan oleh umat manusia, wakaf Wakaf merupakan investasi sebagai dasar dari pengembangan ekonomi, investasi merupakan pengembangan harta seseorang untuk kemudian menjadi modal produksi yang hasilnya dapat dimanfaatkan untuk kegenerasi mendatang dalam hal ini adalah disalurkan kepada mauquf 'alaihi atau penerima manfaat wakaf yang peruntukannya ditentukan oleh wakif atau pemberi wakaf yang dikelola oleh nadzir yang tertuang dalam ikrar wakaf (Ahmad Hidayat, 2017). Nadzir memiliki peran dalam pengelolaan harta wakaf, ada beberapa hal yang harus diperhatikan nadzir bahwa pengelolaan wakaf harus menghasilkan keuntungan, harus konsisten dalam mengelolaannya mengikuti perkembangan teknologi melalui media yang berbasis digital dengan memberikan pelayanan yang terbaik (Syaifullah \& Idrus, 2019)(Haq, Sari, \& Hana, 2020).

\section{Membangun Negeri dengan Wakaf}

Pembangunan di Indonesia tidak telepas dari peran wakaf yang diberikan oleh masyarkat sebagai dukungan kepada pembangunan negara menurut Imam Teguh Saptono (Saptono, 2019) sebagai wakil dari BWI beberapa peninggalan untuk pembangunan Indonesia dibagun dengan wakaf; pesawat Dakota RI-001 Seulawah merupakan pesawat pertama yang di miliki Indonesia merupakan wakaf dari masyarakat Aceh, pesawat Avro Ansor RI-003 merupakan wakaf emas dari masyarakat Sumatera Barat dan Aceh, lingkaran Stadion Gelora Bung Karno juga emas puncak Monas yang merupakan wakaf dari Teungku Markam, bangunan DPR juga wakaf. Pembangunan negara bisa dilakukan melalui wakaf yang merupakan filantropi dalam Islam, bersifat menyerahkan harta seseorang 
untuk di manfaatkan di jalan Allah SWT bisa bersifat sementara atau selamanya untuk kesejahteraan umat sehingga pahalanya akan selalu mengalir sepanjang masa, peran wakaf dalam mendukung pembangunan di Indonesia pada berbagai bidang, yakni:

1. Bidang Pendidikan:

a. Universitas Islam Indonesia (1948) ; wakaf berupa harta bergerak dan harta tetap melaui Yayasan Badan Wakaf UII mendapatkan wakaf dari masyarkat berupa tanah sampai dengan tahun 2011 berjumlah 13, $561 \mathrm{M}^{2}$ yang tersebar pada 9 lokasi (Mu'allim, 2017).

b. Universitas Muslim Indonesia (1953) ; Yayasan Wakaf UMI yang didirikan oleh para raja; H. Andi Mappanyukki (Raja Bone), H. Andi Jemma (Raja Luwu) Andi Ijo Karaeng Lalolang (Raja Gowa) dan Pajonga Karaeng Polongbangkeng (orang terkemuka di daerah Polongbangkeng) dan Pemerintah; Gubernur Sulawesi dan Walikota Makasar pada tanggal 08 Februari 1953 telah berdiri sampai dengan sekarang yang awalnya berkonsentrasi pada bidang pendidikan dan dakwah kemudian tahun 1990-an melebarkan sayap dengan mendirikan rumah sakit Ibnu Sina, di era sekarang membina 3 pilar utama yaitu pendidikan dan dakwah; usaha dan dakwah; kesehatan dan dakwah (Universitas Muslim Indonesia, 2017). Sejak pendiriannya UMI tidaklah berjalan dengan lancar, ada beberapa kejadian yang menjadi krisis internal dan eksternal sejak didirikan pada tanggal 23 Juni 1954 mulai dari para pemimpinnya yang terlibat dalam gerakan PRRI/Permesta, hal lainnya adanya pertentangan kebijakan yaitu ingin menyatukan fakultasfakultas di UMI dengan di IAIN, dimana akhir nya bisa menyelesaikan semua konflik tersebut dan berdiri sampai dengan sekarang (Muchlis, 2018).

c. Universitas Sultan Agung - UNISSULA (1962) ; Yayasan Badan Wakaf Univesitas Islam Sultan Agung (YBWSA) didirikan di Semarang pada tanggal 20 Mei 1962 dengan mencanangkan filosofi dalam pendidikan yaitu bismillah menbangun generasi khaira ummah yang diimplementasikan dengan mendirikan Budaya Akademik Islami (BudAi) yang direalisasikan pada tanggal 18 Agustus 2005 merupakan budaya yang melakukan penguatan ruhiyah yaitu penguatan akidah, ibadah dan akhlak juga pengembangan Iptek (Unissula, 2019). Penelitian yang dilakukan Wahyuningsih (Wahyuningsih \& Widyastuti, 2018) pada YBWSA mendapatkan wakaf dari masyarkat mengalami perkembangan yang luar biasa sejak tahun 1950 sampai dengann 2014 mampu mendirikan sekolah dasar sampai dengan sekolah 
menengah sebanyak 13 sekolah, tahun 1961 mendirikan UNISSULA, rumah sakit pada tahun 1971 namun demikian hasil dari input wakaf (modal, tenaga kerja, aset wakaf) tidak berpengaruh signifikan terhadap prsuktivitas aset wakaf pada YBWSA karena jika ditinjau pada variabel independen (tenaga kerja,modal, aset wakaf) menghasilkan nilai kurang dari 1 artinya bahwa penambahn input akan mengurangi output atau tingkat kesejahteraan input YBWSA sehingga perlu adanya langkah strategis manajemen sumber daya insani seperti evaluasi kerja, peningkatan kualitas melalui pendidikan dan pelatihan, rasionalisasi keja untuk meningkatkan efesiensi kinerja YBWSA.

d. Universitas Dasrussalam Gontor (1963); pada tahun 1958 keluarga K.H. Ahmad Sahal, K.H. Zainuddin Fannani, dan K.H. Imam Zarkasyi mewakafkan lembaga pendidikan, dimulai dari pembangunan masjid pusaka kemudian berkembang menjadi unversitas Islam pada tahun 1963 mendirikan Institut Pendidikan Darussalam kemudian pada tahun 2014 didirikan Universitas Darussalam Gontor (UNIDA, 2020).

2. Bidang Kesehatan

a. Klinik Masjid Agung Semarang dan Klinik Masjid Agung Jawa Tengah

Kedua masjid ini merupakan wakaf produktif yang sudah bisa mengoptimalkan hasilnya dengan mengelola, mengembangkan dalam bidang kesehatan dengan mendirikan klinik kesehatan dimana kedua klinik ini dikelola terpisah dan mempunyai manajemen masing-masing, keduanya memiliki persamaan yaitu sama-sama berasal dari tanah wakaf, dalam pengelolaannya didanai oleh masjid wakaf dengan fasilitas yang sama dengan yang dikelola selain lembaga wakaf (Usman, 2016)

b. Rumah sakit Mata Ahmad Wardi (RSAW)

Rumah sakit mata pertama di dunia yang berbasis wakaf, merupakan wakaf dari keluarga Achmad Wardi dengan nadzir Badan Wakaf Indonesia (BWI) dan Yayasan Dompet Dhuafa (DD) dengan nama Rumah Sakit Mata Achmad Wardi BWI-DD yang beralamat di Jl. Raya Taktakan Km.1 Kelurahan Lontar Baru, Kec. Serang Banten dengan luas tanah 1.420, $48 \mathrm{M}^{2}$ dan luas bangunan mencapai 927,5 M² yang sudah beroperasi sejak tahun 2017 (BWI, 2020b). Rumah sakit ini memiliki fasilitas yang sudah baik dengan layanan unggulan 'vitreoretina dan cataract centre', memiliki teknik operasi tanpa jahit, fasilitas dan penggunaan alat medis terkini, jumlah ruang VIP (1); kelas I (1), kelas II (3) ; kelas III (4); ruang UGD (4); ruang operasi (2) selain fasilitas 
rumah sakit ini mempunyai program donasi bersama \#AksiBaik bersama RSAW Peduli dengan program banten bebas katarak; 1000 kaca mata untuk santri; wakaf alat kesehatan (rsmataachmadwardi, 2020).

c. Rumah Sakit Islam Malang (RSI Malang)

Rumah sakit ini di resmikan pada 28 Agustus 1994 oleh KH.Abduracman Wahid dengan akta notaris no.218 tahun 1996 dengan memiliki 5 orang dokter dan 60 orang (RSI Malang, 2020). RSI Malang dibwah yayasan Uiversitas Islam Malang (Unisma) yang merupakan wakaf dari Yayasan Pendidikan Ma'arif NU yang sudah memiliki fasilitas ; ruang VIP, laboratorium, apotik, ruang inap serta melakukan investasi sebesar 300 juta per tahun untuk membeli alat kesehatan terbaru dengan total aset 50 miliar (Zawawi Muchtar, Khozin Ismail, 2019). Berdasarkan penelitian yang dilakukan oleh Ulinuha bahwa RSI Malang memiliki strategi manajemen yaitu ada strategi manajemen dana berdasarkan tujuan waqif dan UU No. 41 Tahun 2004 serta berdasarkan studi studi kelayakan ; nadzir mendapatkan $10 \%$, mauquf 'alaihi $20 \%$, untuk pengembangan wakaf $70 \%$ semuanya dari total profit namun demikian ada beberapa kendala yaitu kurangnya tempat penyimpanan barang dagangan, merubah mindset dalam memahami wakaf non produktif menjadi wakaf produktif (Ulinnuha, 2019).

3. Bidang Pertanian

a. Tanah Sawah

Pertanian merupakan bidang yang sangat potensial untuk kelangsungan hidup manusia, dimana dari bidang ini tercipta berbagai makanan bagi masyarakat, salah satunya dihasilkan dari pengelolaan wakaf. Salah satu pengelola wakaf pertanian khususnya sawah adalah pondok modern Darussalam Gontor (PMDG) yang sudah melakukan wakaf tanah sawah secara produktif dalam pengelolaan tanah wakaf tersebut namun masih bersifat semi profesional yang dibantu oleh pengawas atau wakil nadzir yang berasal dari tanah itu berada (lokasi wakaf tanah sawah) dengan sistem disewakan, bagi hasil dan digarap sendiri (Masruchin, 2014). Dalam pengelolaan wakaf produktif pada PMDG sudah memberikan kontribusi baik secara internal maupun eksternal, dikelola dengan baik seta disalurkan secara logis dan produktif dalam berbagai bidang usaha, mempunyai dampak bagi perekonomian masyarakat sekitarnya (Fasa, Rofiqo, \& Oktarina, 2016).

Wakaf tanah sawah lainnya adalah yang dikelola oleh Pimpinan Ranting Muhammadiyah Penatarsewu Pimpinan (PRMP) sejak 
tahun 2010 telah mengelola aset wakaf seluas $13.613 \mathrm{~m}^{2}$ yang sudah memberikan manfaat bagi masyarakat dengan sistem bagi hasil 60:40 (Rahman \& Widiastuti, 2020).

b. Perkebunan Buah Naga dan Buah Nanas.

Wakaf produktif bentuk lainnya adalah perkebunan buah naga dan buah nanas yang dikelola oleh Dompet Dhuafa (DD) sejak tahun 2014 di Desa Cicangkrong, Cijambe, Subang, Jawa Barat yang berbentuk agrowisata sebagai pusat wisata dan edukasi pertanian yang telah memberikan manfaat bagi petani dan masyarakat untuk tetap optimis bisa memenuhi kebutuhan hidup (Republika, 2017).

c. Perkebunan Apel

Perkebunan ini berupa wakaf tanah yang kemudian di jadikan wakaf produktif dengan membuat perkebunan apel oleh Yayasan Al Ikhlas Andonosari di Pasuruan, menggunakan sistem bagi hasil dimana pembagiannya sebesar $30 \%$ untuk yayasan dan 70\% untuk petani penggarap (Dirgantari, 2019)

d. 1000 Ha Lahan Pertanian

Pengelolaan tanah wakaf pertanian ini dilakukan oleh rumah zakat seluas 1.000 Ha bertujuan untuk memfungsikan lahan produktif dengan membebaskan lahan yang dapat diberdayakan untuk ketahan pangan masyarakat yang tersebar di 1.056 desadengan 129 kota/kabupaten dalam pembinaan rumah zakat dan 1,6 juta penerima dana ZIS (Republika, 2017).

4. Bidang Ekonomi dan Keuangan

a. Cash Waqaf Linked Sukuk (CWLS)

Merupakan kerjasama antara Badan Wakaf Indonesia (BWI) dan Kemnenterian Keuangan (Kemenkeu), memiliki potensi dalam pembangunan melaui impact investing yaitu uang yang diwakafkan para waqif akan di investasikan dalam sukuk negara khususnya untuk bidang kesehatan dan pendidikan, para wakif dalam pemberian dana wakafnya bisa dilakukan secara permanen atau sementara, dana ini akan disalurkan untuk pengelolaan proyek umat dan sesuai dengan syariah (Wildan, 2019). Sukuk dan wakaf sudah menjadi instrumen investasi yaitu sukuk-wakaf dalam kegiatan ekonomi, mengatasi kesenjangan pendanaan dengan funsi untuk penunjang perputaran uang, investasi dan alat unttuk mencapai pembangunan berkelanjutan (Musari, 2019)(Haq et al., 2020)(Aini, Triyansyah, \& Hana, 2020).

b. Bank Wakaf Tani

Program ini dikeluarkan oleh Kementerian Pertanian yang diperuntukkan untuk petani yang kurang mampu dengan 
menggunakan akad mudharabah atau bagi hasil (Istikomah, 2019b). Pada bank wakaf tani petani hanya mengembalikan pinjaman sebesar dana pinjaman juga biaya administrasi tanpa bunga, jika petani sudah mengalami peningkatan kesejahteraan maka pembiayaan tersebut di alihkan pada petani yang lain yang membutuhkan, peran Bank Wakaf Tani sebagi shohibul mal sementara petani mempunyai peran pengelola dana yang kemudian pembagian keuntungannya sesuai dengan kesepakatan bersama (Istikomah, 2019a).

c. Bank Wakaf Mikro (BWM)

1) Bank Wakaf Mikro (BWM) merupakan bagian dari lembaga keuangan mikro yang didirikan untuk memberikan pengembangan usaha serta pemberdayaan masyarakat, BWM mempunyai karakteristik non deposit taking, imbal hasil rendah (3\%), berbasis kelompok, menyediakan pembiayaan serta pendampingan dan tanpa agunan (Disemadi \& Roisah, 2019). Program BWM merupakan kerjsama antara OJK, Laznas, Tomas, Pondok Pesantren, menurut Ketua Dewan Komisioner OJK Wimboh Santoso (Santoso, 2020) sampai akhir tahun 2019 sudah ada 56 Bank Wakaf Mikro (BWM) dengan penerima manfaat sebanyak 25.631 nasabah, total pembiayaan sebanyak Rp.33, 92 miliar (Santoso, 2020).

2) Berikut adalah daftar Bank Wakaf Mikro (BWM)

Tabel 3.

Bank Wakaf Mikro (BWM)

\begin{tabular}{|c|l|c|l|}
\hline No & \multicolumn{1}{|c|}{ Bank Wakaf Mikro } & No. & \multicolumn{1}{|c|}{ Bank Wakaf Mikro } \\
\hline 1 & $\begin{array}{l}\text { BWM Al Muttaqien Pancasila Sakti } \\
\text { (ALPANSA). Klaten Jawa Tengah }\end{array}$ & 27 & $\begin{array}{l}\text { BWM Ummul Mukminin Aisyiyah. } \\
\text { Makasar, Sulawesi Selatan. }\end{array}$ \\
\hline 2 & $\begin{array}{l}\text { BWM Amanah Berkah Nusantara. } \\
\text { Purwokerto, Jawa Tengah }\end{array}$ & 28 & $\begin{array}{l}\text { BWM Taawun Mitra Ummat. } \\
\text { Balikpapan, Kalimantan Timur. }\end{array}$ \\
\hline 3 & $\begin{array}{l}\text { BWM Ranah Indah Darussalam. Ciamis } \\
\text { Jawa Barat }\end{array}$ & 29 & $\begin{array}{l}\text { BWM Ponpes Minhadlul Ulum. } \\
\text { Pesawaran, Lampung. }\end{array}$ \\
\hline 4 & $\begin{array}{l}\text { BWM Berkah Bersama Baiturrahman. } \\
\text { Bandung Jawa Barat }\end{array}$ & 30 & BWM Al Azhar Jember. Jawa Timur \\
\hline 5 & $\begin{array}{l}\text { Pesantren BWM Buntet Koperasi LKMS } \\
\text { Buntet Pesantren. Cirebon Jawa Barat }\end{array}$ & 31 & BWM AL-Falah Jember \\
\hline 6 & $\begin{array}{l}\text { BWM Denanyar Sumber Barokah. } \\
\text { Jombang Jawa timur }\end{array}$ & 32 & $\begin{array}{l}\text { BWM Ponpes Mawaridussalam. } \\
\text { Deli Serdang, Sumatera Utara }\end{array}$ \\
\hline 7 & $\begin{array}{l}\text { BWM Almuna Berkah Mandiri. Sewon } \\
\text { DIY }\end{array}$ & 33 & $\begin{array}{l}\text { BWM Sinar Mandiri Sejahtera. } \\
\text { Tuban, Jawa Timur }\end{array}$ \\
\hline
\end{tabular}




\begin{tabular}{|c|c|c|c|}
\hline 8 & $\begin{array}{l}\text { BWM Berkah Rizqi Lirboyo. Kediri } \\
\text { Jawa Timur }\end{array}$ & 34 & $\begin{array}{l}\text { BWM Sunan Pandan Aran. Slemen, } \\
\text { DIY. }\end{array}$ \\
\hline 9 & $\begin{array}{l}\text { BWM KHAS KEMPEK. Cirebon Jawa } \\
\text { Barat }\end{array}$ & 35 & $\begin{array}{l}\text { BWM Ponpes As'ad. Danau Teuk, } \\
\text { Jambi }\end{array}$ \\
\hline 10 & $\begin{array}{l}\text { BWM An Nawawi Tanara. Banten Jawa } \\
\text { Barat }\end{array}$ & 36 & $\begin{array}{l}\text { BWM Sunan Gunung Jatu Ba'alawy. } \\
\text { Semarang, Jawa Tengah. }\end{array}$ \\
\hline 11 & $\begin{array}{l}\text { BWM Amanah Makmur Sejahtera. } \\
\text { Kediri Jawa Timur }\end{array}$ & 37 & $\begin{array}{l}\text { BWM Barokah Pesantren Al- } \\
\text { Masthuriyah. Sukabumi, Jawa Barat. }\end{array}$ \\
\hline 12 & $\begin{array}{l}\text { BWM Assa Berkah Sejahtera. Kudus } \\
\text { Jawa Tengah }\end{array}$ & 38 & $\begin{array}{l}\text { BWM Amal Dana Bergulir. Bogor, } \\
\text { Jawa Barat. }\end{array}$ \\
\hline 13 & BWM El Manahij. Banten Jawa Barat & 39 & $\begin{array}{lcc}\text { BWM } & \text { Minhajut } & \text { Thullab. } \\
\text { Banyuwangi, Jawa Timur } & \end{array}$ \\
\hline 14 & $\begin{array}{l}\text { BWM Al Ihya Baitul Auqof. Cilacap, } \\
\text { Jawa Tengah }\end{array}$ & 40 & $\begin{array}{l}\text { BWM Honai Sejahtera Papua. Jaya } \\
\text { Pura }\end{array}$ \\
\hline 15 & BWM Lan Taburo. Banten, Jawa Barat & 41 & $\begin{array}{l}\text { BWM Al Anshor Peduli. Ambon, } \\
\text { Maluku. }\end{array}$ \\
\hline 16 & $\begin{array}{l}\text { BWM Al Manshur Barokahing Gusti } \\
\text { Klaten, Jawa Tengah. }\end{array}$ & 42 & BWM FATAHA. Siak, Riau. \\
\hline 17 & $\begin{array}{l}\text { BWM Nahdlatul Wathon Cijantung. } \\
\text { Ciamis, Jawa Barat }\end{array}$ & 43 & $\begin{array}{l}\text { BWM Al Hidayah Rokan Hulu, } \\
\text { Riau. }\end{array}$ \\
\hline 18 & $\begin{array}{l}\text { BWM Tebuireng Mitra Sejahtera. } \\
\text { Jombang, Jawa Timur }\end{array}$ & 44 & BWM APIK Kendal, Jawa Tengah. \\
\hline 19 & $\begin{array}{l}\text { BWM Bahrul Ulum Barokah Sejahtera. } \\
\text { Jombang, Jawa Timur }\end{array}$ & 45 & $\begin{array}{l}\text { BWM Mantenan Aman Makmur. } \\
\text { Blitar, Jawa Timur }\end{array}$ \\
\hline 20 & $\begin{array}{l}\text { BWM Al Fithrah Wava Mandiri. } \\
\text { Surabaya, Jawa Timur }\end{array}$ & 46 & $\begin{array}{l}\text { BWM Ahmad Taqiuddin Mansur } \\
\text { (ATQIA). Lombok Timur, Nusa } \\
\text { Tenggara Barat. }\end{array}$ \\
\hline 21 & $\begin{array}{l}\text { BWM Kariman Birajuda Al Karimiyyah. } \\
\text { Sumenep, Madura }\end{array}$ & 47 & $\begin{array}{l}\text { BWM Syubbanul Wathon Maslahah. } \\
\text { Magelang, Jawa Tengah }\end{array}$ \\
\hline 22 & $\begin{array}{l}\text { BWM PPM Al Kautsar. Limapuluh, } \\
\text { Sumatera Barat. }\end{array}$ & 48 & $\begin{array}{l}\text { BWM Pesantren Hidayatulloh. } \\
\text { Tenggaralek, Jawa Timur. }\end{array}$ \\
\hline 23 & BWM UNISA. Sleman, DIY & 49 & $\begin{array}{l}\text { BWM Al Fadlu Kendal, Jawa } \\
\text { Tengah. }\end{array}$ \\
\hline 24 & $\begin{array}{l}\text { BWM Ponpes Futuhiyyah. Demak, } \\
\text { Jawa Barat. }\end{array}$ & 50 & $\begin{array}{l}\text { BWM Al Hijrah Cindai Alus. Banjar, } \\
\text { Kalimantan Selatan. }\end{array}$ \\
\hline 25 & $\begin{array}{l}\text { BWM Sinar Sukses Bersama. Malang, } \\
\text { Jawa Barat }\end{array}$ & 51 & $\begin{array}{l}\text { BWM Aulia Cendekia. Sukarami, } \\
\text { Palembang }\end{array}$ \\
\hline 26 & $\begin{array}{l}\text { BWM Imam Syuhodo. Sukoharjo, Jawa } \\
\text { Tengah }\end{array}$ & 52 & $\begin{array}{l}\text { BWM Babul Maghfirah. Kuta Baro, } \\
\text { Aceh Besar. }\end{array}$ \\
\hline
\end{tabular}

5. Bidang Teknologi

Teknologi akan mempermudah kehidupan termasuk dalam keuangan Islam yang akan berdampak sosial, berdampak pada pemangku kepentingan melalui jalur investasi dan dengan bantuan teknologi blockchain dan fintech (Alam, 2018)

a. Digitalisasi Wakaf Blockchain 
Merupakan inovasi pada wakaf digital dengan program ini seluruh transaksi wakaf bisa diawasi dan bersifat trasnparan, ada beberpa keuntungan dengan menggunakan sistem blockchain yaitu transaksi donasi wakaf akan dilakukan secara simultan; digital serta transparan, yang kedua peengelolaan wakaf produktif bersifat inklusif pada skala global (para wakif dapat mewakafkan dananya ke seluruh dunia karena sudah menggunakan teknologi digital), blockchain merupakan rekaman bersama atas transaksi digital yang menghubungkan wakif dan nadzir serta mauquf 'alaihi yang saling mengawasi sehingga memperkecil penyalahgunaan dalam pengelolaan wakaf (Mubarok, 2020). Blockchain dimulai dari proses penghimpunan, pengelolaan, pengembangan, distribusi wakaf secara tepat sasaran sehingga transparansi pengelolaannya lebih baik sehingga kemaslahatan bagi umat lebih dirasakan secara luas (Budiantoro, Wardhani, Hasanatina, \& Putra, 2020)

b. Waqf Core Principles (WCP)

Menurut UU nomor 40 tahun 2004 tentang wakaf mempunyai peran untuk memberikan kesejahteraaan dan untuk mendukung pembangunan namun demikian ada beberapa kendala untuk hal tersebut diantaranya kurangnya pengengetahuan tentang fikih wakaf serta regulasinya, tentang komitmen nadzir untuk mengelola barang wakaf, pendanaan, lemahnya pengawasan, jika hal-hal tersebut sudah mempunyai solusi yang tepat maka akan menunjukkan peran wakaf sebagai instrumen syariah yang dapat mensejahterakan umat dan mendukung pembangunan (Ash-Shiddiqy, 2019). Untuk mengatasi permasalahan tersebut maka pada tanggal 14 Oktober 2018 merupakan standar Internasional pengelolaan dan pengawasan wakaf yang di perkenalkan oleh 10 perwakilan negara dalam International Working Grup (IWG), WCP-IWG terdiri dari Islamic Development Bank, World Bank, Badan Wakaf Indonesia (BWI), Bank Indonesia (BI), Kementerian Agama (Kemenag), perwakilan dari negara; Kuwait, Bosnia, Selandia Baru, Australia, Afrika Selatan; WCP menggunakan technical note untuk menjelaskan standar peaksanaan wakaf agar efektif, efisien dan sesuai syariah sehingga dapat meningkatkan kualitas sistem wakaf dengan mengidentifikasi kelemahan dalam pengawasan, regulasi wakaf (Sutan Emir Hidayat, 2020).

\section{KESIMPULAN}

Wakaf merupakan memeberikan harta kita untuk Allah SWT dengan cara menahan pokok harta dan hasil investasinya yang bisa dikembangkan oleh 
pada nadzir kemudian hasilnya disalurkan pada mauquf 'alaihi sebagai penerima manfaat. Ada berbagai jenis wakaf yang bisa di salurkan oleh wakif kepada nadzir untuk dikembangkan, peran wakaf dalam pembangunan tidak bisa dibilang kecil karena dengan wakaf dapat merubah keadaan menjadi lebih sejahtera dimana wakaf memiliki fungsi sebagai ibadah kepada Allah SWT dan sebagai kegiatan sosial. Kegiatan sosial inilah yang menjadi pendorong pembangunan negeri seperti pada bidang pendidikan, kesehatan, pertanian, ekonomi dan keuangan, serta bidang teknologi yang saat ini bidang-bidang tersebut mejadi bidang yang penting dalam pembangunan negeri.

\section{DAFTAR PUSTAKA}

Alam, Nafis. (2018). Islamic Finance and Business: Capital, Commerce, \& Careers. Proceedings of Harvard University Muslim Alumni Islamic Finance Conference.

Ali, Khalifah Muhamad, Yuliani, Meida, Mulatsih, Sri, \& Abdullah, Zaki. (2018). Aspek-Aspek Prioritas Manajemen Wakaf di Indonesia. ALFALAH: Journal of Islamic Economics, 3(1), 1-28.

Aini, N., Triyansyah, T., \& Hana, K. F. (2020). Obligasi Daerah Yang “Tak Kunjung" Terbit Sebagai Salah Satu Faktor Perkembangan Daerah. MABSYA: Jurnal Manajemen Bisnis Syariah, 2(1), 71-90.

Aziz, Muhammad. (2017). Peran Badan Wakaf Indonesia (BWI) dalam mengembangkan prospek wakaf uang di Indonesia. JES (Jurnal Ekonomi Syariah), 1(2).

Budiantoro, Risanda A., Wardhani, Masitha Fahmi, Hasanatina, Foza Hadyu, \& Putra, Febrianur I. F. S. (2020). Waqf Blockchain Untuk Pengadaan Alat Kesehatan Penanganan Covid-19: Studi Konseptual. ZISWAF: Jurnal Zakat Dan Wakaf, 7(2), 133-150.

BWI. (2020a). Pengertian Wakaf. Retrieved September 23, 2020, from BWI website: https://www.bwi.go.id/pengertian-wakaf/

BWI. (2020b). Rumah Sakit Mata Achmad Wardi. Retrieved September 1, 2020, from bwi.gi.id website: https://www.bwi.go.id/4019/2019/11/18/mengenal-lebih-dekat-rumah-sakitmata-berbasis-wakaf-pertama-di-dunial

Dahlan, Rahmat. (2016). Analisis Kelembagaan Badan Wakaf Indonesia. ESENSI: Jurnal Bisnis Dan Manajemen, 6(1), 113-124.

Dirgantari, Rafida. (2019). Implementasi Pengelolaan Wakaf Produktif Berupa Perkebunan Apel Tahun 2018 di Yayasan Al-Ikhlas Andonosari (Ya-Ikhsan) Pasuruan. UIN Sunan Ampel Surabaya.

Disemadi, Hari Sutra, \& Roisah, Kholis. (2019). Kebijakan Model Bisnis Bank Wakaf Mikro Sebagai Solusi Pemberdayaan Ekonomi Masyarakat. Law Reform, 15(2), 177-194. 
Fahrurroji. (2020). Tujuan Dasar Berwakaf. Retrieved September 23, 2020, from BWI website: https://www.bwi.go.id/5561/2020/09/22/tujuan-dasarberwakaf/

Fasa, Muhammad Iqbal, Rofiqo, Azidni, \& Oktarina, Amimah. (2016). Model Pengembangan Wakaf Produktif Pondok Modern Darussalam Gontor Ponorogo. Al-Awqaf: Jurnal Wakaf Dan Ekonomi Islam, 9(2).

Fuadi, Nasrul Fahmi Zaki. (2018). Wakaf Sebagai Instrumen Ekonomi Pembangunan Islam. Economica: Jurnal Ekonomi Islam, 9(1), 151-177. https:/ / doi.org/10.21580/economica.2018.9.1.2711

Hadi, Solikhul. (2018). Pemberdayaan Ekonomi melalui Wakaf. ZISWAF: Jurnal Zakat Dan Wakaf, 4(2), 229-244. https://doi.org/10.21043/ziswaf.v4i2.3043

Haq, M. R., Sari, D. P. F., \& Hana, K. F. (2020). Peran Sukuk Terhadap Pembangunan Infrastruktur. Al-Mutharahah, 17(1), 87-103. Retrieved from http:/ /ojs.diniyah.ac.id/index.php/Al-Mutharahah

Hidayat, Ahmad. (2017). Wakaf Produktif. Bil Dalil, 1(01), 1-30.

Hidayat, Sutan Emir. (2020). Terapkan Waqf Core Principles, Ini yang Dilakukan KNEKS. Retrieved September 2, 2020, from knks website: https://knks.go.id/berita/262/terapkan-waqf-core-principles-ini-yangdilakukan-kneks? category=1

Istikomah, Istikomah. (2019a). Menggagas Bank Wakaf Tani (Bwt) Sebagai Upaya Meningkatkan Kesejahteraan Petani Lokal Di Era Disrupsi. AtTasharruf: Jurnal Kajian Ekonomi Dan Bisnis Syariah, 1(2), 70-78.

Istikomah, Istikomah. (2019b). Penguatan Sektor Pertanian Melalui Bank Wakaf Tani Berbasis Mudharabah. TAWAZUN: Journal of Sharia Economic Law, 2(2), 135-146.

Itang, Itang, \& Syakhabyatin, Iik. (2017). Sejarah Wakaf di Indonesia. Tazkiya, 18(02), 220-237.

Kamaluddin, Imam. (2020). Fiqih Wakaf \#1. Jawa Timur: Divisi Edukasi Publik dan Literasi Wakaf - ICAST UNIDA Gontor.

Lahuri, Setiawan. (2020). Fiqif Wakaf \#2. Jawa Timur: Divisi Edukasi Publik dan Literasi Wakaf - ICAST UNIDA Gontor.

Laz DD. (2019). Lembaga Wakaf di Indonesia. Retrieved September 23, 2020, from zakat.or.id website: https://zakat.or.id/sepak-terjang-5lembaga-wakaf-di-indonesial

Lestari, Ana Indah. (2018). Revitalisasi Wakaf Untuk Kemaslahatan Umat. ZISWAF: Jurnal Zakat Dan Wakaf, 4(1), 55-72.

Masruchin, Masruchin. (2014). Wakaf Produktif dan Kemandirian Pesantren: Studi Tentang Pengelolaan Wakaf Produktif di Pondok Modern Darussalam Gontor Ponorogo. UIN Sunan Ampel Surabaya.

Mu'allim, Amir. (2017). Ijtihad Ekonomi dalam Pengelolaan Aset Wakaf. AL-'ADALAH, 14(2), 291-310. 
Mubarok, Acep Zoni Saeful. (2020). Prospek Nazhir Wakaf Global Berbasis Pesantren di Era Digital. Jurnal Bimas Islam, 13(1), 23-50. https:/ / doi.org/10.37302/jbi.v13i1.190

Muchlis, Anna Asriani. (2018). Bertahan Di Tengah Krisis: Pendirian Universitas Muslim Indonesia (Umi) Makassar, 1945-1965. Lensa Budaya: Jurnal Ilmiah Ilmu-Ilmu Budaya, 12(2).

Musari, Khairunnisa. (2019). The Evolution of Waqf and Sukuk toward Sukuk-Waqf in Modern Islamic Economy. IJUS: International Journal of Umranic Studies.

Naim, Abdul Haris. (2019). Lembaga Pengelola Wakaf dan Manajemen Fundraising. ZISWAF: Jurnal Zakat Dan Wakaf, 6(1), 101-113. https:/ / doi.org/10.21043/ziswaf.v6i1.5613

Nissa, Choirun. (2017). Sejarah, Dasar Hukum dan Macam-Macam Wakaf. Tazkiya, 18(02), 205-219.

Nizar, Muhammad Afdi. (2017). Pengembangan Wakaf Produktif di Indonesia: Potensi dan Permasalahan.

UU No.41 Tahun 2004 Tentang Wakaf

Rahman, Inayah, \& Widiastuti, Tika. (2020). Model Pengelolaan Wakaf Produktif Sektor Pertanian untuk Meningkatkan Kesejahteraan Petani (Studi Kasus Pimpinan Ranting Muhammadiyah Penatarsewu Sidoarjo). Jurnal Ekonomi Syariah Teori Dan Terapan, 7(3), 486-498. https:/ / doi.org/10.20473/vol7iss20203pp486-498

Republika. (2017, October 26). Wakaf Produktif Pertanian Sejahterakan Petani Subang. Republika.Co.Id. Retrieved from https://republika.co.id/berita/oyfmmj396/wakaf-produktif-pertaniansejahterakan-petani-subang

RSI Malang. (2020). Sejarah RSI Malang. Retrieved September 1, 2020, from rsunisma website: https://www.rsiunisma.com/sejarah/

RS Mata Achmad Wardi. (2020). Fasilitas Rumah Sakit Mata Achmad Wardi. Retrieved September 1, 2020, from Rumah Sakit Achmad Wardi website: https://rsmataachmadwardi.com/fasilitas

Said, Salmah, \& Amiruddin, Andi Muhammad Ali. (2019). Wakaf Tunai dan Pemberdayaan Ekonomi Masyarakat. Al-Mashrafiyah: Jurnal Ekonomi, Keuangan, dan Perbankan Syariah, 3(1), 43-55.

Santoso, Wimboh. (2020). Hingga 2019, Bank Wakaf Mikro Salurkan Pembiayaan Rp33,9M. Retrieved from https://www.wartaekonomi.co.id/read265751/hingga-2019-bank-wakafmikro-salurkan-pembiayaan-rp339-m

Saptono, Imam Teguh. (2019). Bukti Wakaf Masyarakat Bagi Pembangunan. $\quad$ Retrieved from https://www.gomuslim.co.id/read/news/2019/07/10/13275/-p-ini-buktiwakaf-masyarakat-indonesia-bagi-pembangunan-indonesia-p-.html 
Sari, Syaputri Febriana. (2018). Pengertian Wakaf. Retrieved September 23, 2020, website: https://zakat.or.id/pengertian-wakaf/

Sholihin, Ahmad Ifham. (2010). Buku Pintar Ekonomi.

Siwak Kemenag. (2020a). Jumlah Tanah Wakaf Indonesia. Retrieved September 24, 2020, from siwak.kemenag.co.id website: http://siwak.kemenag.go.id/tabel_jumlah_tanah_wakaf.php

Siwak Kemenag. (2020b). Penggunaan Tanah Wakaf. Retrieved September 24, 2020, from siwak.kemenag.co.id website: http://siwak.kemenag.go.id/index.php

Syaifullah, Hamli, \& Idrus, Ali. (2019). Inovasi Pelayanan Wakaf Produktif Era Digital: Studi Kasus Di Yayasan Wakaf Bani Umar 2018. ZISWAF: Jurnal Zakat Dan Wakaf, 6(2), 114-128.

Ulinnuha, Imada. (2019). Strategi Manajemen Dana pada Pengembangan Wakaf Produktif: Studi pada Yayasan UNISMA Malang. UIN Sunan Ampel Surabaya.

UNIDA. (2020). Universitas Darussalam Gontor. Retrieved September 29, 2020, from gontor.ac.id website: https://www.gontor.ac.id/institut-studiislam-darussalam\#

Unissula. (2019). Universitas Sultan Agung. Retrieved from unissula.ac.id website: http:/ / unissula.ac.id/sejarah-unissula/

Universitas Muslim Indonesia. (2017). Sejarah UMI. Retrieved September 29, 2020, from umi.ac.id website: https://www.umi.ac.id/tentangkami/profil-dan-sejarah-umi

Usman, Nurodin. (2016). Pengelolaan Wakaf Produktif Untuk Kesehatan (Studi Kasus Bandha Wakaf Masjid Agung Semarang). Muaddib: Studi Kependidikan Dan Keislaman, 4(2), 1-20. https:/ / doi.org/10.24269/muaddib.v4i2.98

Wahyuningsih, Wahyuningsih, \& Widyastuti, Tika. (2018). Efisiensi Wakaf Produktif Pada Yayasan Badan Wakaf Sultan Agung Semarang. AlAwqaf: Jurnal Wakaf dan Ekonomi Islam, 11(2), 141-152.

Wildan, Muhammad. (2019). Wakaf Miliki Peran Besar dalam Pembangunan. Retrieved September 1, 2020, from ekonomi.bisnis.comwebsite: https://ekonomi.bisnis.com/read/20190725/9/1128809/wakaf-miliki-peranbesar-dalam-pembangunan-ini-penjelasannya

Yuliafitri, Indri, \& Rivaldi, Arie Indra. (2017). Pengaruh Penerapan PrinsipPrinsip Good Governance dan promosi terhadap penerimaan wakaf tunai (pada lembaga pengelola wakaf di Indonesia). InFestasi (Jurnal Bisnis Dan Akuntansi), 13(1), 217-226.

Zawawi Muchtar, Khozin Ismail, Ahmad Shodiqy. (2019). RSI Malang. Retrieved September 1, 2020, from bwi.go.id website: https://www.bwi.go.id/295/2008/12/24/wakaf-produktif-untuk-rumah-sakit/ 
Zuchdi Darmiyati Afifah, Wiwiek. (2019). Analisis Konten Etnografi, Grounded Theory, Hermeneutika dalam Penelitian. Jakarta: Bumi Aksara. 